\title{
Work environment and health in the fishing fleet: results from a survey amongst Norwegian fishers
}

\author{
Signe Annie Sønvisen, Trine Thorvaldsen, Ingunn M. Holmen, Anita Øren
}

SINTEF Ocean, Torgarden, Trondheim, Norway

\begin{abstract}
Background: Fishery is an important industry in Norway. Compared to other industries the number of occupational accidents is high. Fishers are exposed to a range of unfavourable working conditions, but there is limited research-based knowledge about the interaction between working conditions and health. The aim of the article is to study fishers' 1) work-related exposures and health complaints, 2) sickness absence, 3) subjective perception of health status and 3) level of job satisfaction.

Materials and methods: Data was gathered through a telephone survey. The survey included questions about exposure, health complaints, health status and job satisfaction. Methods for analysis were descriptive statistics and relative risk (RR).

Results: A total of 830 full-time fishers were interviewed. Coastal fishers are more exposed to factors such as climatic $(R R=1.546,95 \%$ confidence interval $[\mathrm{Cl}] 1.311-1.823)$, ergonomic $(R R=1.539$, $95 \% \mathrm{Cl} 1.293-1.833)$ and processing $(R R=2.119,95 \% \mathrm{Cl} 1.847-2.431)$, compared to other groups of fishers. Coastal fishers are also more likely to experience musculoskeletal problems ( $R R=1.623,95 \%$ Cl 1.139-2.314), sickness absence $(R R=1.337,95 \% \mathrm{Cl} 1.081-1.655)$ and to perceive their own health as poor $(R R=2.155,95 \% \mathrm{Cl} 1.119-4.152)$. Purse sein fishers are less exposed to climatic $(R R=0.777$, $95 \% \mathrm{Cl} 0.633-0.953)$, ergonomic $(R R=0.617,95 \% \mathrm{Cl} 0.487-0.783)$ and processing $(R R=0.292,95 \% \mathrm{Cl}$ 0.221-0.385) factors and are less likely to experience sickness absence ( $R R=0.635,95 \% \mathrm{Cl} 0.479-0.840)$. In terms of job satisfaction, 99\% of our respondents enjoy their work.

Conclusions: Norwegian fishers have a high degree of job satisfaction and overall good health. Challenges regarding health complaints and exposures in the working environment were identified. This may be helpful for the industry, showing where measures should be implemented to prevent exposure, illness and sickness absence. Findings may also serve as a basis for future intervention studies aimed at promoting healthy working environments for fishers, especially how to improve vessels and develop user-friendly technology to reduce risk of injuries and strain.
\end{abstract}

(Int Marit Health 2017; 68, 4: 203-210)

\section{Key words: work environment, health, job satisfaction, work exposure, fishers, fishermen}

\section{INTRODUCTION}

The fisheries is a leading export industry providing jobs, income and economic and social spin-off effects throughout Norwegian society [1]. Statistically, fishing is associated with a high number of occupational accidents. A total of 306 work-related fatalities were registered amongst Norwegian fishers (fisher, rather than fisherman, is increasingly being used in a range of disciplines. We have chosen fisher, as it is a more inclusive and gender neutral term [2]) between 1990 and 2015 [3]. Furthermore, there is also a high occurrence of personal injuries, which may lead to sick leave and longterm consequences such as disability [4-6].

Fishers are exposed to a combination of unfavourable exposures, including ship motion, cold, noise, heavy lifting, inconvenient work hours, long work days and excessive strain [3]. A recent article argues that fishers' awareness of the risk of developing chronic diseases leading to permanent incapacity should be raised through health promotion 
and education [7]. However, research-based knowledge about the interaction between work conditions and health of Norwegian fishers is limited.

Overall, musculoskeletal diseases (MSD) are the most common diagnosis for sick leave in Norway [8, 9]. In fisheries, musculoskeletal stress is exacerbated by physical and manual labour (i.e. lifting and carrying), repetitive motions, awkward or static work postures, vessel vibration and movement, rough weather and water, and long work periods [10-12]. A recent Danish study concludes that despite positive developments in the physical work environment, fishers still experience a heavy workload and suboptimal ergonomic conditions [13]. Consequently, fishers suffer from MSD, including pain in lower back, hands or wrists [14]. A recent study of Norwegian fishers, found that about $50 \%$ of fishers' doctor-certified sick leave in 2013 was due to MSD (Øren et al. in progress). Despite many work related challenges, previous studies have also found factors that promote occupational health and well-being. This includes fresh air, connection to nature and physical work [15]; as well as work environment, friendship, cooperation and finding the work itself meaningful [16].

To prioritise measures to prevent exposures, illness and absence, and promote healthy work environments, more research-based knowledge is needed. Accordingly, the objective of this article is to study how fishers perceive their own health and well-being, given the conditions they are exposed to and the physical and psychological health complaints they are experiencing. The following research questions will be answered:

- What work-related exposures and health complaints do fishers report in various modes of operation?

- What is the extent of and reasons for sickness absence according to the fishers themselves?

- What are the fishers' perceptions of their own health status?

- What is the level of job satisfaction among fishers?

\section{THE NORWEGIAN FISHING FLEET}

The Norwegian fishing fleet is made up by approximately 6,100 vessels that employ around 10,000 fishers [17]. Specific quota systems regulate who can fish what, how, where and when. Due to modernisation in the fishing fleet, the number of vessels and fishers has been radically reduced in the last 40 years [18].

The fleet consist of several types of vessels, commonly divided into the coastal fleet and the deep-sea fleet. The coastal fleet, of about 5,800 vessels, consists of vessels below $28 \mathrm{~m}$, with the majority under $15 \mathrm{~m}$, whereas the deep-sea fleet consists of vessels over $28 \mathrm{~m}$, mostly trawlers, longliners and seiners.

The organisation of the work depends on vessel size and modes of operation, or fishing gear used. Jigging, gill- nets, line and hand-lines are common fishing gears in the smallest coastal vessels. In addition to lines and gillnets, larger coastal vessels also use Danish seines, trawls and purse seines. Deep-sea vessels use trawls, purse seines and autolines (longliners using automatic baiting systems). The latter two vessel categories utilise more technology and less manual labour compared to the smallest vessels in the coastal fleet.

The smallest coastal vessels, with one or two crewmembers, operate on a daily basis out of their homeport. Deepsea vessels can have a crew of around 15-30 people and stay at sea for periods up to 8 weeks. Work on deep-sea fishing vessels is organised in shifts, usually $6 \mathrm{~h}$ on and $6 \mathrm{~h}$ off. In all fleet categories, during peak fishing seasons, crew may work long hours and get little sleep for days.

Norwegian health, safety and environment regulations regulate work and spare time on-board to ensure health, well-being and welfare of fishers [19]. Fishers in the deep-sea fleet have to undergo a mandatory health screenings to receive the so-called seaman's licence. This includes checking vision, hearing, weight and presence of specific diseases and disorders. The purpose is to ensure that the fisher "is not suffering from any disease likely to be aggravated by or to render him unfit for service at sea or likely to endanger the health of other persons on board" [20]. Fishers that are at sea for less than three consecutive days or work on vessels below 100 gross tons are exempt from this requirement.

\section{MATERIALS AND METHODS}

The material presented here is based on a quantitative survey carried out in the spring of 2014. The study population is Norwegian full-time professional fishers and respondents were sampled randomly from the Norwegian official fisher registry. (Registry of full-time fishers [Blad-B], received from the Norwegian Directorate of Fisheries in 2014 [Fiskarmanntallet].) Although registration is not mandatory, the majority of fishers are registered, as this qualifies for social security benefits.

A questionnaire that included basic information about the informants and their perceptions regarding work exposures, health complaints and status and job satisfaction was designed. The questions were a mix of closed and open-ended questions [21]. Closed questions were answered on a four- or five-point Likert Scale. A professional polling agency conducted the survey by telephone and participation was voluntary. One thousand fishers participated.

Data was analysed using Excel and SPSS and focused on differences in exposure and complaints in different modes of operation, as well as fishers' perceptions of their own health and job satisfaction. The analysis was carried out in three steps. First, general frequency tables described the respondent population. Second, to limit the number of variables and 
Table 1. Description of exposure index

\begin{tabular}{ll}
\hline Variable & Index \\
\hline Exposed to strong wind? & $\begin{array}{l}\text { Climatic } \\
\text { conditions }\end{array}$ \\
Work in cold environment? & \\
Freeze at work? & \\
Work in moist environment? & \\
\hline Repetitive and monotonous work operations? & Ergonomic \\
Heavy lifting? & \\
Lift with upper body twisted or bent? & \\
Work with hands above shoulders? & \\
\hline High level of noise (stand close or scream)? & Factory \\
Work in dusty environment? & \\
Splash from machines? & \\
Exposed to cleaning detergents or disinfectants? & \\
\hline $\begin{array}{l}\text { Contact with fish/fishmeal? } \\
\text { Gutting or processing 50\% of the time? }\end{array}$ & Processing \\
\hline $\begin{array}{l}\text { Experience stress? } \\
\text { Organisation of your work (shift etc.) demanding? }\end{array}$ &
\end{tabular}

ease interpretation, formative indicators (a formative index is an index of a weighted sum of variables; the assumption is that the variables cause the constructed index and as such variables do not necessarily correlate) [22] were developed for exposure (Table 1) and complaints (Table 2).

For exposures we constructed indices for: climatic conditions, ergonomic exposures, factory exposures, processing exposures and psychological exposures (as seen in Table 1). For instance, for climatic conditions four variables were used: exposed to strong winds, work in cold environment, freeze at work and work in humid environment. The average value for the variables was calculated, and to allow for the calculation of relative risk (RR), binary indices were constructed. Hence, values above 3.5 were set to 1 (exposure) and below 3.5 were set to 0 (non-exposure). Same method was used for all the exposure indices, as well as for experienced ailment (shown in Table 2).

Third, to show the differences in exposures and complaints between operations, RR ratio was used. RR is an intuitive way to compare risk between groups [23] and is the ratio of probability of an event (e.g. health complaint) occurring in one group (e.g. trawl fishers) to the probability of the event occurring in a comparable group (e.g. coastal fishers) [24]. The RR is presented by the following formula:

$$
\text { Relative risk }(\mathrm{RR})=\frac{\text { Risk in exposed population }}{\text { Risk in non-exposed population }}
$$

If $R R>1$, the risk in the exposed population is greater than the risk in the non-exposed population. If $R R=1$ there
Table 2. Description of complaints index

\begin{tabular}{ll}
\hline Ailments & Index \\
\hline Neck/shoulder/arm pain & Musculoskeletal \\
Back pain & \\
Knee/hip pain & Psychological \\
\hline Headaches & \\
Mental health problems (anxiety, & \\
depression, sadness) & \\
Problems sleeping & Hearing \\
\hline Reduced hearing & \\
Tinnitus & Allergy/Sensitivity \\
\hline Airway symptoms & \\
Eye problems & \\
Skin problems (eczema, rash) & \\
White finger & \\
Allergic reactions and sensitivity & \\
\hline Gastrointestinal problems \\
Cardiovascular problems
\end{tabular}

is no difference between the two populations, and if $R R<1$ then the risk in the exposed group is less than in the non-exposed population [25]. In our analysis, the control group is made up by fishers in all the other modes of operation, except the one in focus (exposed population).

All data has been handled according to the principles of the Data Protection Authority and the Norwegian Centre for Research Data (NSD).

\section{RESPONDENTS}

\section{RESULTS}

Of the one thousand participants, 830 were still active fishers. The rest had left fishing recently, mostly due to old age. The average age of the active fishers was 50 years - the youngest 17 and the oldest 76 years old. On average, they have worked as fishers for about 25 years. The survey data was found to be representative of the Norwegian official fishery registry in terms of sex, age and geography (see [3] for details).

Respondents were divided into groups according to the mode of operations on the vessel they work. This categorisation allowed the exploration of the interaction between types of fishing gear, exposures and health complaints.

The largest number of informants came from the conventional coastal fleet (42\%), which includes jig, gillnets and coastal line. (Coastal vessels using Danish seine are also included in conventional coastal fishing, but we have chosen to keep it separately, as this mode of 
Table 3. Distribution of informants in terms of age, experience, vessel size, operation and position $(n=830)$

\begin{tabular}{|c|c|c|c|c|c|}
\hline Age & Number & Percentage & Operation (multiresponse) & Number & Percentage \\
\hline$<30$ years & 95 & $11 \%$ & Autoline & 73 & $9 \%$ \\
\hline $30-39$ years & 98 & $12 \%$ & Coastal fishing & 350 & $42 \%$ \\
\hline $40-49$ years & 200 & $24 \%$ & Danish seine & 72 & $9 \%$ \\
\hline $50-59$ years & 221 & $27 \%$ & Purse seine & 231 & $28 \%$ \\
\hline$>60$ years & 216 & $26 \%$ & Trawl & 199 & $24 \%$ \\
\hline \multirow[t]{2}{*}{ Total } & 830 & $100 \%$ & Other & 44 & $3 \%$ \\
\hline & & & Total & 830 & $115 \%$ \\
\hline Fishing experience & Number & Percentage & Position & Number & Percentage \\
\hline Under 6 years & 98 & $12 \%$ & Net man & 13 & $2 \%$ \\
\hline $6-10$ years & 68 & $8 \%$ & Factory & 13 & $2 \%$ \\
\hline $11-15$ years & 92 & $11 \%$ & Fisher & 213 & $26 \%$ \\
\hline Over 15 years & 572 & $69 \%$ & Fisher apprentice & 7 & $1 \%$ \\
\hline \multirow[t]{2}{*}{ Total } & 830 & $100 \%$ & Engineer & 63 & $8 \%$ \\
\hline & & & Skipper & 344 & $41 \%$ \\
\hline Vessel size & Number & Percentage & Steward & 22 & $3 \%$ \\
\hline Under $11 \mathrm{~m}$ & 237 & $28 \%$ & Mate & 47 & $6 \%$ \\
\hline $11-14.9 \mathrm{~m}$ & 112 & $13 \%$ & Other & 108 & $13 \%$ \\
\hline $15-20.9 m$ & 65 & $8 \%$ & Total & 830 & $100 \%$ \\
\hline $21-27.9 \mathrm{~m}$ & 55 & $7 \%$ & & & \\
\hline $28 \mathrm{~m}$ or over & 361 & $44 \%$ & & & \\
\hline Total & 830 & $100 \%$ & & & \\
\hline
\end{tabular}

Table 4. The relative risk of exposures in different modes of operation (fishing gear)

\begin{tabular}{llllll}
\hline & Climatic & Ergonomic & Factory & Processing & Psychological \\
\hline Autoline & $0.875(0.636-1.206)$ & $1.185(0.899-1.562)$ & $0.561(0.138-2.279)$ & $1.018(0.808-1.283)$ & $1.403(0.976-2.017)$ \\
Coastal fishing & $1.546(1.311-1.823)$ & $1.539(1.293-1.833)$ & $0.202(0.080-0.510)$ & $2.119(1.847-2.431)$ & $1.126(0.879-1.442)$ \\
Danish seine & $0.889(0.646-1.223)$ & $0.721(0.492-1.058)$ & $1.548(0.625-3.835)$ & $1.155(0.938-1.421)$ & $1.083(0.711-1.649)$ \\
Purse seine & $0.777(0.633-0.953)$ & $0.617(0.487-0.783)$ & $0.894(0.443-1.805)$ & $0.292(0.221-0.385)$ & $0.657(0.478-0.902)$ \\
Trawl & $0.752(0.603-0.938)$ & $0.818(0.654-1.024)$ & $\mathbf{2 . 4 5 0 ( 1 . 3 2 8 - 4 . 5 2 1 )}$ & $\mathbf{0 . 7 0 2}(0.581-0.847)$ & $0.855(0.630-1.161)$
\end{tabular}

In bold - Pearson Chi-square, asymptotic significance (2-sided), 95\% confidence interval

operation may be quite different from the other coastal operations.) Purse seining and trawl fishing represented $28 \%$ and $24 \%$ of the respondents, respectively. In terms of vessel size, the largest numbers of informants are from vessels $28 \mathrm{~m}$ long and over (44\%) and from vessel under $11 \mathrm{~m}$ (28\%). The largest shares of informants have the position skipper (41\%) and fisher (26\%). These results are reasonable, as the smallest vessels (usually owner-operated) are largest in number and large deepsea vessels have the largest number of crew (defined as fishers) (Table 3).

\section{ASSOCIATIONS BETWEEN WORK-RELATED EXPOSURES AND HEALTH COMPLAINTS}

In this section, we investigate the question: What exposures and health complaints do fishers in various modes of operation experience? Fishers were asked to rate different exposures in their work on the scale: never, seldom, sometimes and often (the latter two responses are used in this analysis).

Table 4 shows the RR of exposure in the different operational modes, with a $95 \%$ confidence intervals $(\mathrm{Cl})$ in parenthesis. The results show that fishers in the coastal fleet have 1.5 times higher RR of climatic and ergonomic 
Table 5. The relative risk of various complaints in given modes of operation (fishing gear)

\begin{tabular}{lllll}
\hline & Musculoskeletal & Psychological & Hearing & Internal \\
\hline Autoline & $1.310(0.755-2.271)$ & $3.457(0.957-12.487)$ & $1.944(0.995-3.800)$ & - \\
Coastal fishing & $1.623(1.139-2.314)$ & $0.980(0.313-3.061)$ & $1.324(0.803-2.185)$ & $3.200(0.833-12.288)$ \\
Danish seine & $0.967(0.511-1.831)$ & - & $0.585(0.188-1.824)$ & $1.170(0.150-9.103)$ \\
Purse seine & $0.524(0.323-0.850)$ & $0.864(0.236-3.165)$ & $0.620(0.327-1.176)$ & $1.111(0.290-4.261)$ \\
Trawl & $0.685(0.428-1.095)$ & $0.634(0.140-2.870)$ & $0.937(0.515-1.703)$ & $0.352(0.045-2.764)$
\end{tabular}

In bold - Pearson Chi-square, asymptotic significance (2-sided), 95\% confidence interval

exposures (i.e. lifting) and 2.1 times higher RR of processing exposures (i.e. contact with fish), compared to fishers in all other operational modes. Purse seine fishers have lower RR for climatic, ergonomic, processing and psychological exposures (RR of $0.8,0.6,0.3$ and 0.7 , respectively), compared to the other operations. Fishers in trawl fishing have 2.5 times higher RR of being exposed to factors typically found in a factory environment, but lower RR for climatic and processing exposure (RR of 0.8 and 0.7 , respectively).

Table 5 presents the RR for the different complaints in the various modes of operation, with a $95 \% \mathrm{Cl}$ in parenthesis. The ratios show, although low in absolute numbers and not statistically significant, that fishers in autoline fishing have 3.5 times higher RR of experiencing psychological complaints compared to other operations. Fishers in coastal fishing have 1.6 times higher RR of experiencing musculoskeletal pains, whereas fishers in purse seining have a lower RR of experiencing musculoskeletal pains (RR of 0.5), compared to other operations.

Fishers' perceptions of the interaction between work, work environment and health complaints were explored by asking fishers whether they worried about their work affecting their health now, or in the long term. Forty-two per cent of fishers worry about work affecting their health negatively, which was particularly related to work strain.

Fishers were also asked whether they believed that their health complaints were completely or partially caused by their work situation. Eighty-four percent of fishers, who had health complaints, associated their complaints with work. Health complaints most commonly linked to work was pains in the neck/shoulders/arms, back pain, pain in the knees/ hips, white fingers, and tinnitus/hearing trouble. Few fishers linked cardiovascular disorders, respiratory disorders, eye problems and mental sufferings to their work.

\section{SELF-REPORTED SICKNESS ABSENCE}

Sickness absence has been found to be an indicator for health and job satisfaction [26]. This raises the question what is the extent of and reasons for sickness absence according to the fishers themselves? Respondents were asked whether they had been absent (this is self-reported
Table 6. The relative risk of sickness absence given various modes of operation (fishing gear)

\begin{tabular}{ll}
\hline & Relative Risk \\
\hline Autoline & $0.999(0.685-1.458)$ \\
Coastal fishing & $1.337(1.081-1.655)$ \\
Danish seine & $0.806(0.524-1.239)$ \\
Purse seine & $0.635(0.479-0.840)$ \\
Trawl & $0.818(0.624-1.072)$
\end{tabular}

In bold - Pearson Chi-square, asymptotic significance (2-sided), 95\% confidence interval

sickness absence, not sick leave certified by a medical doctor) due to sickness or injuries during the last 12 months, and the duration and cause of the absence. About 30\% had sickness absence during the last twelve months. Of these, almost $40 \%$ had been away more than eight weeks in total. The most common reason for absence was injuries related to work (53\%), whereas illness related to work accounted for only $10 \%$. The remaining absences were due to sickness or injuries not related to work.

The following section presents the RR of sickness absence in the various modes of operation. Table 6 shows that the RR of absence (with $95 \% \mathrm{Cl}$ in parenthesis) in the coastal fleet is almost 34\% higher than in all the other modes of operation. Furthermore, in purse seining the RR of absence is almost $37 \%$ lower, compared to all the other modes of operation.

There were no significant differences between age groups in terms of sick leave; however, sick leave for the age group 30 to 50 years old was almost significant with a $22 \%$ higher chance of sick leave (RR of $1.219,95 \% \mathrm{Cl}$ 0.983-1.513), compared to the other age groups (under 30 years old and over 50 years old).

\section{SELF-REPORTED HEALTH STATUS}

The following two sections answer the question: What are the fishers' perceptions of their own health and job satisfaction? Fishers were asked to assess their own over-all health, rating it on a scale from very poor, poor, neither good nor poor, good or very good. Seventy-seven per cent of the respondents perceived their health to be good or very good. 
Table 7. The relative risk of fishers perception of their health in given modes of operation (fishing gear)

\begin{tabular}{lll}
\hline & Good health & Poor health \\
\hline Autoline & $0.895(0.766-1.045)$ & $1.673(0.671-4.170)$ \\
Coastal fishing & $0.952(0.882-1.027)$ & $\mathbf{2 . 1 5 5 ( 1 . 1 1 9 - 4 . 1 5 2 )}$ \\
Danish seine & $1.026(0.906-1.162)$ & $1.316(0.479-3.617)$ \\
Purse seine & $1.098(1.019-1.183)$ & $0.741(0.343-1.602)$ \\
Trawling & $1.001(0.918-1.091)$ & $0.288(0.089-0.930)$
\end{tabular}

In bold - Pearson Chi-square, asymptotic significance (2-sided), 95\% confidence interval

Table 7 presents the RR of perceiving health as either good or poor in the various modes of operation, compared to fishers in all other modes of operation $(95 \% \mathrm{Cl}$ in parenthesis). The table shows that fishers in purse seining have a RR of 1.1 and are therefore $10 \%$ more likely of perceiving their health as good, compared to fishers in all other operations. Fishers in coastal fishing, however, have over 2 times higher RR of perceiving their health as poor ( RR = $=2.155$ ), whereas trawl fishers have a lower RR of perceiving their health as poor ( $R R=0.288$ ), compared to fishers in all other operational modes.

Table 8 shows that the RR of reporting good health decreases with age. Fishers under the age of thirty are $21 \%$ more likely to report of good health, whereas fishers over 50 years have a lower RR of experience good health (about 8\%).

\section{JOB SATISFACTION}

Finally, the level of job satisfaction among fishers was explored, showing that $99 \%$ enjoy their work always or most of the time. This is high compared to both the general employed population in Norway and the global population, in which $70 \%$ or $62 \%$ were satisfied, respectively [27].

In an occupation characterised by relative high levels of fatalities and injuries, the high level of job satisfaction may be surprising. Thus, to get more details, fishers were asked about the reasons for their job satisfaction. Table 9 shows that the main reasons for the high level of job satisfaction was friendships (34\%). In addition, independence (23\%) and that the job is rewarding and meaningful (22\%) also contributed to job satisfaction.

\section{DISCUSSION}

One of the challenges in the interpretation of the results is that fishers and vessels often combine modes of operations. For instance, a number of vessels combine quotas in cod and pelagic fisheries; thus, fish with trawl in the cod fisheries and purse seine in the pelagic fisheries. Similarly, due to the inherent seasonality in fisheries, fishers combine work in different fisheries. As a result, we could not completely isolate modes of operation. Among our respondents
Table 8. The relative risk (RR) of experiencing good health in relation to age

\begin{tabular}{ll}
\hline & Good health \\
\hline Under 30 years & $1.213(1.127-1.305)$ \\
30 to 50 years & $1.003(0.929-1.083)$ \\
Over 50 years & $0.916(0.852-0.986)$
\end{tabular}

In bold - Pearson Chi-square, asymptotic significance (2-sided), 95\% confidence interval

Table 9. Causes of job satisfaction among Norwegian fishers $(n=818)$

\begin{tabular}{lll}
\hline $\begin{array}{l}\text { What makes you thrive at } \\
\text { work? (multiresponse) }\end{array}$ & Number & Percentage \\
\hline Friendship & 281 & $34 \%$ \\
Independence & 191 & $23 \%$ \\
My interest for fishing & 120 & $15 \%$ \\
The work is rewarding & 112 & $14 \%$ \\
Variation & 101 & $12 \%$ \\
Good income opportunities & 70 & $9 \%$ \\
The work is meaningful & 64 & $8 \%$ \\
Many fishers in the family & 11 & $1 \%$ \\
A duty to carry on the tradition & 1 & $0 \%$ \\
No other work opportunities & - & $0 \%$ \\
Total & 951 & $116 \%$
\end{tabular}

the most common combinations were Danish seine/purse seine (27 respondents) and trawl/purse seine (59 respondents). However, we attempted to catch the main exposures by asking what vessel they work on the most and the main mode of operation on that vessel.

Another factor that affects the answers is that age is not equally distributed across modes of operation. As we find the older fishers in the coastal fleet, we would also expect to find more ailments among these fishers. Thus, due to the effect of aging, we should expect that young fishers more often experience their health as good, compared to older fishers. 
The results show that coastal fishers are more exposed to climatic, ergonomic and processing factors; and are more likely to experience musculoskeletal problems and absence from work, compared to fishers in other modes of operation. In comparison, fishers in the purse seine fleet are less exposed to climatic, ergonomic and processing factors, and less likely to be absent from work due to illness or injury. Furthermore, coastal fishers are more likely to experience their health as poor or very poor, whereas purse seine fishers are more likely to experience their health as good or very good.

These results correspond well with the distinctive characteristics of the different modes of operation. As small coastal vessels often do not have sheltered decks, fishers in this fleet are exposed to climatic factors, such as wind and cold. In spite of great technological improvements, space limits the amount of technology on-board and coastal fishers still rely on a fair amount of manual labour. Purse seining, on the other hand, is a completely different mode of operation, where fishers are sheltered from climatic factors and where technology has eased the requirement of manual labour.

Given the findings presented here, it seems as though little has changed in the last 30 years. An interview-based study conducted in 1981 [15] found that musculoskeletal symptoms were the most common diagnosis for sick leave amongst fishers, accounting for $1 / 3$ of all cases. Reported injuries were frequent, while mental illness was hardly reported at all. The author linked this to substantial under-reporting and workplace norms encouraging repression of pain and health problems.

In general, fishers in all operations reported of good health and a high level of job satisfaction. This is related to friendship, work environment, independence and meaningful work. Despite harsh work conditions, Grinde (1987) [15] also found several favourable and health promoting factors such as closeness to nature, fresh air and physical work. Cooperation, unity and friendship were found to be important features of fishing, promoting job satisfaction and work participation. The coastal culture and the close relation between input and outcome give meaning to the fishers' work efforts.

\section{CONCLUSIONS}

Findings from a large survey amongst Norwegian fishers show that fishers in general experience their health as good and have a high degree of job satisfaction, implying that there are some lessons to be learned for creating health promoting work places in other industries. However, several challenges regarding health complaints and exposures in the working environment were identified, and many fishers worry that work may negatively affect their health. These findings are helpful for the industry, showing where they should implement measures to prevent exposure, illness and sick leave. Findings may also serve as a basis for future intervention studies aimed at promoting healthy work environments for fishers. In particular, knowledge about exposure and health in different modes of operation should be used to improve vessels and develop user-friendly technology. This may reduce the risk of injuries and strain, consequently leading to reduction of sick leave and withdrawal from work life.

\section{ACKNOWLEDGEMENTS}

This article a part of the research project "Working environment and health in the Norwegian fishing fleet challenges and health promoting factors" funded by the Norwegian Research Council. We would like to thank all informants for their time and contribution. We would also like to thank the project's research group for valuable input throughout the research project.

\section{REFERENCES}

1. Richardsen R, Bull-Berg H. Nasjonal betydning av sjømatnæringen. En verdiskapingsanalyse med data fra 2014. Trondheim: SINTEF; 2016.

2. Branch $T$, Kleiber D. Should we call them fishers or fishermen? Fish and Fisheries. 2015; 18(1): 114-127, doi: 10.1111/faf.12130.

3. Thorvaldsen T, Sønvisen SA, Holmen IM, et al. Fiskerhelseundersøkelsen -Sammenhenger mellom arbeid, arbeidsmiljø og helse hos norske yrkesfiskere. Trondheim: SINTEF Fiskeri og havbruk, 2016 Contract No. : A27653.

4. Lindøe P, Engen O, Olsen 0 . Responses to accidents in different industrial sectors. Safety Science. 2011; 49(1): 90-97, doi: 10.1016/j.ssci.2009.12.007.

5. McGuinness E, Aasjord H, Utne I, et al. Injuries in the commercial fishing fleet of Norway 2000-2011. Safety Science. 2013; 57: 82-99, doi: 10.1016/j.ssci.2013.01.008.

6. McGuinness E, Aasjord H, Utne I, et al. Fatalities in the Norwegian fishing fleet 1990-2011. Safety Science. 2013; 57: 335-351, doi: 10.1016/j.ssci.2013.03.009.

7. Jensen AO. Prevalence of Health Risk Factors among Fishermen A Review. Occup Med Health Aff. 2014; 02(02), doi: 10.4172/23296879.1000157.

8. Ose SO. Kunnskap om sykefravær: nye norske bidrag. Trondheim: SINTEF. 2010.

9. Lærum E, Brage S, Ihlebæk C, et al. Et muskel- og skjelettregnskap Forekomst og kostnader knyttet til skader, sykdommer og plager i muskel-og skjelettsystemet. Oslo: Oslo Universitetssykehus. 2013.

10. Törner M, Almström C, Karlsson R, et al. Working on a moving surface - a biomechanical analysis of musculo-skeletal load due to ship motions in combination with work. Ergonomics. 1994; 37(2): 345-362, doi: 10.1080/00140139408963651, indexed in Pubmed: 8119265.

11. Fulmer S, Buchholz B. Ergonomic exposure case studies in Massachusetts fishing vessels. Am J Ind Med. 2002; Suppl 2: 10-18, doi: 10.1002/ajim.10086, indexed in Pubmed: 12210677.

12. Kucera K, McDonald M. Occupational stressors identified by smallscale, independent commercial crab pot fishermen. Safety Science. 2010; 48(5): 672-679, doi: 10.1016/j.ssci.2010.01.019.

13. Østergaard H, Jepsen JR, Berg-Beckhoff G. The workload of fishermen: a cross sectional survey among Danish commercial 
fishermen. Int Marit Health. 2016; 67(2): 97-103, doi: 10.5603/ IMH.2016.0019, indexed in Pubmed: 27364175.

14. Lipscomb HJ, Loomis D, McDonald MA, et al. Musculoskeletal symptoms among commercial fishers in North Carolina. Appl Ergon. 2004; 35(5): 417-426, doi: 10.1016/j.apergo.2004.04.004, indexed in Pubmed: 15246880.

15. Grinde J. Ondt ofte lider den fiskermand? Helse og arbeidsmiljø i fiskeryrket. Fiskeriteknologisk Forskningsinstitutt Nf, editor. Oslo: Oslo Universitetsforlaget. 1987.

16. Johnsen JP, Vik J. Mellom marked og nettverk: Om fiskerirekruttering og sysselsettingssystemer i fiske. Trondheim: Bygdeforsking. 2008; 7: 08.

17. DoF. Statistikkbank (statistics) Bergen: Directorate of Fisheries; 2016 [cited 2017.28.11].

18. Standal D, Hersoug B. Back to square one? Fisheries allocation under pressure. Marine Policy. 2014; 43: 236-245, doi: 10.1016/j. marpol.2013.06.004.

19. Forskrift om arbeidsmiljø, sikkerhet og helse for de som har sitt arbeid om bord på skip. 2005.
20. C073-Medical Examination (Seafarers) Convention. 1946(No. 73).

21. Bernard HR. Research methods in anthropology : qualitative and quantitative approaches. Walnut Creek CA: AltaMira; 2006. xiii, 666.

22. Ringdal K. Enhet og mangfold : samfunnsvitenskapelig forskning og kvantitativ metode. Bergen: Fagbokforlaget. 2007.

23. Viera AJ. Odds ratios and risk ratios: what's the difference and why does it matter? South Med J. 2008; 101(7): 730-734, doi: 10.1097/ SMJ.0b013e31817a7ee4, indexed in Pubmed: 18580722.

24. Weddell A, Winters M, Teschke K. Evidence from Safety Research to Update Cycling Training Materials in Canada Vancouver: The University of British Columbia \& Simon Fraser University. 2012.

25. Sukon Kanchanaraksa. Estimating risk Baltimore, MA: Johns Hopkins University; 2008. http://ocw.jhsph.edu/courses/fundepiii/ pdfs/lecture16.pdf([cited 2016.15.6.]).

26. Corne AMR, Koopmans PC, Notenbomer A, et al. Job satisfaction and sickness absence: a questionnaire survey. Occupational Medicine. 2008; 58(8): 567-571, doi: 10.1093/occmed/kqn113.

27. Ennova. European Employee Index 2014. Oslo: Ennova. 2014. 